\title{
The Role of Biodiversity in Food Security and Nutrition: A Potato Cultivar Case Study
}

\author{
Carmen van Niekerk1,2, Hettie Schönfeldt1,2, Nicolette Hall1,2, Beulah Pretorius ${ }^{1,2}$ \\ ${ }^{1}$ Department Animal and Wildlife Science, Faculty Natural and Agricultural Science, University of Pretoria, \\ Pretoria, South Africa \\ ${ }^{2}$ Institute of Food Nutrition and Well-Being, University of Pretoria, Pretoria, South Africa \\ Email: u29293295@tuks.co.za
}

Received 22 October 2015; accepted 25 April 2016; published 28 April 2016

Copyright (C) 2016 by authors and Scientific Research Publishing Inc.

This work is licensed under the Creative Commons Attribution International License (CC BY).

http://creativecommons.org/licenses/by/4.0/

(c) (i) Open Access

\begin{abstract}
Biodiversity is considered a critical measure of the agricultural health of the world. Not only does increased biodiversity contribute to nutrient production and consumption, but it acts as a safeguard against food shortages due to pests and diseases by spreading the risk. Biodiversity can improve dietary diversity in such a way to ultimately contribute to improved food and nutrition security. As a result biodiversity is often highlighted in global discussions related to food and nutrition security. Potatoes (Solanum tuberosum L.) are highly biodiverse food crops, with more than 4000 different cultivars grown globally. The crop is sometimes considered as part of the vegetable component of food baskets, but it is mainly added to meals as a starch because potatoes have a high starch content and are thus high in energy. However, significant differences in the nutritional content (including micronutrient composition) of different potato cultivars have been reported in many countries. It is therefore proposed that specific cultivars could potentially contribute more to critical nutrients required in the diet of countries at risk of malnutrition. The nutritional profile (macronutrients and minerals) of 11 potato cultivars cultivated in sub-Saharan Africa was determined and the contribution which these different potatoes could make to the diet, and consequently to food and nutrition security, is discussed. The results showed that significant differences are found in the nutritional content between the different cultivars. Significant differences ( $p<$ 0.001) were found in macronutrients such as protein and fat as well as micronutrients such as copper, phosphorus and potassium. These results indicate the potentially beneficial role which a biodiverse range of crops such as potatoes, could play in the food and nutrition security of developing countries.
\end{abstract}

\section{Keywords}

Potatoes, Solanum tuberosum, Nutrient Content, Biodiversity, Sub-Saharan, Food and Nutrition Security 


\section{Introduction}

Food, as well as the lack thereof, has a significant impact on human health, therefore food and nutrition security, dietary adequacy and biodiversity are currently amongst the most vigorously discussed global topics in the field of nutrition [1] [2]. Even though these topics have been main focus areas in the field of nutrition for many years, resulting in slow to moderate changes in the nutrition status of populations [3], little progress is observed in sub-Saharan countries [4]. The Millennium Development Goal, 1C related to halving under nutrition in developing countries was not reached in 2015, particularly not so in sub-Saharan Africa [5] [6]. This slow progress is often blamed on population growth, poor agricultural conditions and environmental changes, etc., which place strain on food production and food security [5].

Individuals who are food secure and have the ability to acquire adequate food for a healthy and active life [7], are more likely to be able to contribute significantly to the economy than their undernourished counterparts [8]. Globally food programmes are being implemented to fight food and nutrition insecurity [9]. Even though these programmes lead to a decrease in food insecurity, very little change is observed in nutrition security, while a drastic increase in obesity rates tends to occur [10] [11]. These programmes are mainly focused on supplying food insecure individuals with energy dense food to combat food insecurity rather than nutrient dense foods to achieve both food and nutrition security [12]. Staple foods in Third World Countries include fortified bread and maize products that do not supply individuals with all the nutrients necessary for good health. Furthermore these diets are supplemented by increased consumption of high fat foods [13]. This monotonous consumption of staple foods and fat is leading to stunting in young children and under nutrition (lack of certain essential nutrients) in adults [14] [15].

The main cause of stunting is under nutrition, which (despite various interventions) is increasing in subSaharan Africa. In the age group 0 - 3 years $26.9 \%$ of boys and $25.9 \%$ of girls were stunted in 2012 as opposed to $19 \%$ of boys and $16 \%$ of girls in 2008 [11]. Sub-Saharan countries are faced with hidden hunger (micronutrient deficiency), which is seen in children and adults. These individuals suffer from micronutrient deficiencies most commonly due to a lack of fruit and vegetables in their diets [16]. Eighteen out of 20 top countries that suffer from hidden hunger, are in sub-Saharan Africa [17].

These countries are also faced with the growing occurrence of overweight and obesity. According to the South African National Health and Nutrition Examination Survey (SANHANES) 24.8\% of females are overweight and $39.2 \%$ are obese. It was reported that $20.2 \%$ of males and $68.2 \%$ of females were at risk of metabolic complications due to their weight [11] [18]. These figures are high when compared to other developing countries. Brazil has lower obesity rates, only $12.5 \%$ of males and $16.9 \%$ of females are obese [19].

Promoting agricultural diversity can lead to dietary diversity through increased consumption of different cultivars of fruits and vegetables [20]. The United Nations (UN) together with the International Institute for Sustainable Development listed biodiversity as one of the most important aspects of food and nutrition security because it has the potential to decrease the occurrence of micronutrient deficiency [25].

\subsection{Potatoes in South Africa}

South Africa is classified as a country with high biodiversity levels [21]. Potatoes are one of the crops that contribute to this high biodiversity score with more than 80 registered cultivars. These tubers are grown in 16 production regions in the country [22]. Due to the biodiversity of these tubers, they can be grown in a variety of agronomical conditions by commercial and subsistence farmers [23]. Because these tubers are nutrient dense carbohydrate, they can form part of an affordable balanced diet along with other starches such as bread and maize meal [24]. The tubers are cheaper than cereals and provide more nutrients per monetary unit than any other carbohydrate crop, thus making them a noteworthy contributor to food and nutrition security [25] [26]. Furthermore they fit into the Food and Agricultural Organisation (FAO) goals of promoting crops that are locally available and that are adapted to cultivation practices of the countries in question [25].

Even though there are so many cultivars available, the nutritional value of only one cultivar is recorded in the South African Food Composition Tables. In 2000, a South African cultivated cultivar, known as BP1, was the market leader with a $43 \%$ market share. Although not recorded, it is generally accepted that it was this cultivar that was analysed for nutrient content in 1999 and included in the national food composition database. At that time the Department of Health commissioned analyses of fruit and vegetables and all samples were purchased 
from the fresh fruit and vegetable market in Johannesburg [27]. It is therefore probable that BP1 values were used in the South Africa Food Composition Tables.

Over the last decade the market share held by different cultivars has changed drastically as shown in Table 1. New cultivars that are higher yielding, disease resistant and suited for specific agronomical conditions are constantly being developed. When farmers start using these new cultivars, changes in production patterns occur [28] which lead to changes in consumption. By 2012, BP1 only comprised 1\% of the market, while Mondial was the market leader with a market share of $63 \%$ compared to 2000 when it only had an $8 \%$ market share [22] [29]. These changes seen in consumption of different cultivars motivate the need for the nutritional analysis of different cultivars.

\subsection{Objective}

The objective of this case study was to explore the reported differences between the nutrient values of different potato cultivars to determine the contribution which these different cultivars could make to food and nutrition security.

\section{Material and Methods}

\subsection{Sampling and Sample Preparation}

The cultivars with the largest market share, as well as those with the greatest potential for growth, as identified by Potatoes South Africa, were chosen for the study. The cultivars included Mondial, Fabula, Buffelspoort (BP13), BP1, Van der Plank, Fianna, Valor, Sifra, Up-To-Date, Darius, Avalanche. See Table 2 for a description of the eleven cultivars included in the study.

Seed potatoes of each cultivar included in the study were provided by Potatoes South Africa. The potatoes were planted on a commercial potato farm in Reitz situated in the Eastern Free State Province, the largest potato production area in South Africa [22]. These tubers were grown under controlled dry land conditions during the summer of 2012/2013 according to normal commercial potato agronomy practices. All the tubers were planted on the same plot of land with the same watering, sunshine, fertilizer and treatment applications. The potatoes were harvested on the $11^{\text {th }}$ of April 2013. After the harvest, the tubers of each cultivar were randomly selected and packed into two brown 10kg bags and transported on the following day to the Agricultural Research Council (ARC) at Irene, Pretoria. The potatoes were kept in a cool dark room at $20^{\circ} \mathrm{C}$ for 7 days to mimic market conditions. After storage, five average sized tubers from each cultivar were randomly selected. These tubers were thoroughly washed with distilled water to remove excess dirt and dried on absorbent paper at room temperature. The tubers were sliced in half perpendicular to the core as shown in Figure 1. One half was peeled and the skin on the other half was not removed, this was done separately. Samples were individually grated, sealed in ziplock plastic-bags and sent to the laboratory for freeze-drying. Freeze-dried samples were stored at $20^{\circ} \mathrm{C}$. Freezedrying the grated tubers ensured that the dried product retained its nutritional value [31].

Table 1. Change in market share of potato cultivars from 2000 to 2013 [22] [29].

\begin{tabular}{|c|c|c|c|}
\hline Cultivar & 2000 & 2009 & 2012 \\
\hline & $\%$ & $\%$ & $\%$ \\
\hline BP1 & 43 & 14 & 1 \\
\hline Up-to-date & 22 & 5 & 5 \\
\hline Buffelspoort & 10 & 4 & 0 \\
\hline Mondial & 8 & 65 & 63 \\
\hline Van der Plank & 5 & 2 & 2 \\
\hline Sifra & 0 & 0 & 16 \\
\hline Other & 12 & 10 & 13 \\
\hline
\end{tabular}

* Other includes all other cultivars cultivated in South Africa. 
Table 2. Description of the eleven potato cultivars identified for sampling [28] [30].

\begin{tabular}{|c|c|c|c|c|}
\hline Cultivar & Shape & $\begin{array}{l}\text { Colour of the } \\
\text { skin and flesh }\end{array}$ & $\begin{array}{l}\text { Classification } \\
\text { system }\end{array}$ & Cooking characteristics \\
\hline Mondial & Oval & White & Waxy & An ideal boiling potato as it does not slough. \\
\hline Fabula & Oval & Light yellow & Waxy & Suited for boiling and baking. \\
\hline Buffelspoort & Round-Oval & White & Waxy & Ideal for boiling as it retains its shape. \\
\hline BP1 & Flat Oval & White & Waxy/Floury & $\begin{array}{l}\text { Combination potatoes lend themselves to a variety of } \\
\text { cooking techniques, especially boiling and roasting. }\end{array}$ \\
\hline Van der Plank & Oval-Pear & White & Waxy/Floury & $\begin{array}{c}\text { Can be prepared using a variety of cooking techniques. } \\
\text { Best suited for boiling and frying. }\end{array}$ \\
\hline Fianna & Oval & Light yellow & Waxy/Floury & $\begin{array}{c}\text { Can be used in the processing industry as it is firm with } \\
\text { a fluffy mouthfeel. }\end{array}$ \\
\hline Valor & Oval & Cream white & Waxy/Floury & $\begin{array}{l}\text { Ideal roasting potatoes as they keep their form and } \\
\text { have a fluffy mouthfeel. }\end{array}$ \\
\hline Sifra & Round & White & Waxy/Floury & $\begin{array}{l}\text { An all-round potato that is ideally suited for most } \\
\text { cooking techniques. }\end{array}$ \\
\hline Up-To-Date (UTD) & Flat Oval & Cream white & Floury & Floury texture, makes this potato ideal for mash. \\
\hline Darius & Oval & White & Floury & Floury texture but keeps its shape when cooked. \\
\hline Avalanche & Oval & White & Floury & $\begin{array}{l}\text { Good for roasting, frying and mash with a fluffy } \\
\text { texture. }\end{array}$ \\
\hline
\end{tabular}

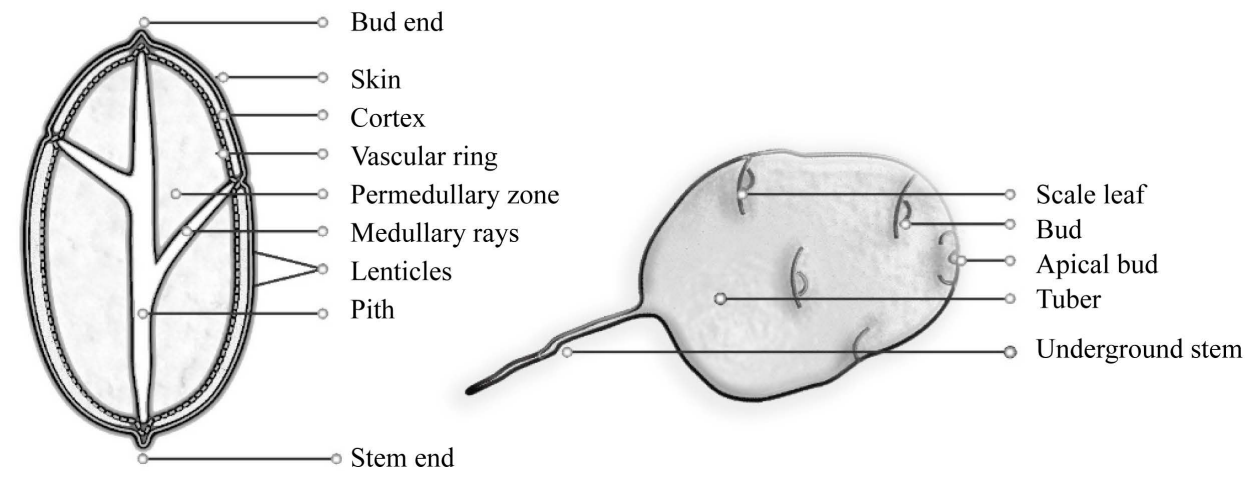

Figure 1. Potato tuber sliced perpendicular to the core (FAO, 1998).

\subsection{Analysis}

The nutritional analyses were performed on a double-blind basis at NutriLab, University of Pretoria, South Africa. A composite sample consisting of 5 randomly selected raw tubers was used for evaluation with and without skin. Samples were analysed in duplicate according to the methods summarized in Table 3 . To ensure accuracy of the assays, standard reference samples were included in all batches of samples analysed. The laboratory is certified by the Agri-Laboratory Association of Southern Africa (AgriLASA) as a laboratory participating in their quality control programmes.

\subsection{Statistical Analyses}

Data received from the laboratory was arranged in tabular format and statistically analysed using the GenStat for Windows (2008) statistical computer programme [35]. A one-way analysis of variance (ANOVA) test was applied with Fisher's protected $t$-test least significant difference at the $5 \%$ level of significance among cultivar means. The mean nutritional values of the "flesh only potatoes" was statistically compared to the nutritional value of the "flesh and skin potatoes" at a $1 \%$ level of significance. 
Table 3. Analytical methods used for nutrient analysis.

\begin{tabular}{cc}
\hline Analysis & Method \\
\hline Moisture (water) & AOAC, 2000. Official method of analysis $934.01^{*}$ \\
Ash & AOAC, 2000. Official method of analysis $942.05^{*}$ \\
Protein (N) & AOAC, 2000. Official method of analysis $968.06^{*}$ \\
Fat & AOAC, 2000. Official method of analysis $920.39^{*}$ \\
Energy (calculated) & Greenfield, H. and Southgate, D.A.T., 2003 \\
Carbohydrates (calculated) & Greenfield, H. and Southgate, D.A.T., 2003 \\
Available carbohydrates & fibre) (Ferreira, 2014) \\
Starch & Available carbohydrates $=$ Dry Matter - Protein (neutral detergent \\
Minerals & Enzymatic spectrophotometer (In-house method) \\
\hline
\end{tabular}

${ }^{*}[33] ;{ }^{*}[34]$.

\section{Results and Discussion}

\subsection{Contribution to Nutrient Reference Values Made by Potatoes}

In sub-Saharan countries maize and wheat are common staple crops, but they need further processing to produce staple foods (maize meal porridge and brown bread) [36]. Both of these products are fortified. Contrary to this, potatoes are a crop that grow easily. It can be grown by subsistence farmers and requires very little to no further processing [37]. Potatoes can be classified as a nutrient dense carbohydrate [38], which together with other staples can improve dietary diversity [39].

It has been proposed that potatoes are most commonly consumed without the skin. Therefore it was necessary to identify whether there is a significant difference in the nutritional values of tubers with or without skin.

Potatoes contain a variety of minerals that are required in the human diet. Tubers contain large amounts of carbohydrate, they do not contribute significantly to protein intake and are naturally low in fat. Very few significant differences in the nutritional value of the tubers with and without the skin were observed. Significant differences were observed in the minerals; calcium ( $p=0.009)$, iron $(p \leq 0.001)$ and manganese $(p \leq 0.001)$. Higher levels of calcium and iron were found in potato samples consisting of flesh and skin, while manganese values were higher in tubers without the skin, indicating that manganese storage occurs in the flesh (Table 4). Values for phosphorus, magnesium, copper, zinc, potassium and sodium did not differ significantly between tubers with and without the skin. Even though there are only a few minerals that differ significantly in mineral concentration of tubers with and without the skin, the skin plays a cardinal role in preventing nutrients from being leached out during the cooking process.

In the rest of this paper only the nutritional values of tubers without the skin (Table 5), will be presented. Table 6 is also included to illustrate the nutritional values of tubers with the skin however only calcium, iron and manganese differed significantly from the nutritional value of tubers without the skin.

\subsection{Nutritional Analysis of Potato Tubers (Flesh Only) from Eleven Cultivars}

The energy content of potatoes is almost entirely derived from the carbohydrate content as 95\% of total energy typically comes from the carbohydrates present within the tuber. This makes potatoes a nutrient dense source of energy that contains easily digestible carbohydrates which is essential for human existence [41]. As expected these carbohydrates are almost entirely made up of starch. The average carbohydrate content of the cultivars included in the study was $16.8 \mathrm{~g} / 100 \mathrm{~g}$ with an average starch content of $15.2 \mathrm{~g} / 100 \mathrm{~g}$ (Table 5). A similar study conducted in Latvia found the average starch content of local Latvian potatoes to be 18.72 g/100g [42]. Energy and carbohydrate values had a high correlation $(\mathrm{r}=0.9938)$. In the current study, the Darius cultivar had the highest energy (380 kJ/100g) and the highest carbohydrate contents (18.6 g/100g) and Van der Plank the lowest energy (240 kJ/100g) and second lowest carbohydrate content (13.7 g/100g) after Fianna (21.8 g/100g). Energy 
Table 4. The average nutrient content of eleven different potato cultivars, per $100 \mathrm{~g}$ raw potato (flesh and skin) and skin only.

\begin{tabular}{ccccccc}
\hline Nutrient & Unit & $\mathrm{p}-$ value & Flesh only & \% of NRV & Flesh and skin & $\%_{\text {of NRV }}^{*}$ \\
\hline Energy (calculated) & $\mathrm{g}$ & 0.513 & 282 & - & 290 & - \\
Protein & $\mathrm{g}$ & 0.673 & 1.37 & 2.68 & 1.33 & 2.38 \\
Fat & $\mathrm{g}$ & 0.425 & 0.0177 & 0.09 & 0.0239 & 0.145 \\
Available carbohydrates & $\mathrm{g}$ & 0.472 & 15.2 & - & 15.7 & - \\
Calcium & $\mathrm{mg}$ & 0.009 & $4.03^{\mathrm{a}}$ & 0.31 & $4.82^{\mathrm{b}}$ & 0.371 \\
Phosphorus & $\mathrm{mg}$ & 0.857 & 50.3 & 4.02 & 49.8 & 3.98 \\
Magnesium & $\mathrm{mg}$ & 0.968 & 25 & 6.83 & 24.9 & 6.82 \\
Copper & $\mathrm{mg}$ & 0.089 & 0.107 & 11.9 & 0.0945 & 10.5 \\
Iron & $\mathrm{mg}$ & $<0.001$ & $0.742^{\mathrm{a}}$ & 5.71 & $1.17^{\mathrm{b}}$ & 9 \\
Manganese & $\mathrm{mg}$ & $<0.001$ & $1.41^{\mathrm{b}}$ & 61.3 & $1.09^{\mathrm{a}}$ & 47.4 \\
Zinc & $\mathrm{mg}$ & 0.653 & 0.371 & 3.71 & 0.362 & 3.62 \\
Potassium & $\mathrm{mg}$ & 0.515 & 439 & 9.34 & 453 & 9.64 \\
Sodium & $\mathrm{mg}$ & 0.693 & 8.01 & 0.4 & 8.16 & 0.408 \\
\hline
\end{tabular}

*NRV for individuals 4 years and older [40].

Table 5. Nutrient content per $100 \mathrm{~g}$ of raw potato, flesh only.

\begin{tabular}{|c|c|c|c|c|c|c|c|c|c|c|c|c|c|}
\hline $\begin{array}{l}\text { Nutrient } \\
\text { (flesh only) }\end{array}$ & Units & p-value & VDP & UTD & Sifra & Valor & BP1 & Mondial & Avalanche & $\begin{array}{l}\text { Buffelspoort } \\
\text { (BP13) }\end{array}$ & Darius & Fabula & Fianna \\
\hline $\begin{array}{c}\text { Energy } \\
\text { (calculated) }\end{array}$ & $\mathrm{kJ}$ & $<0.001$ & $240^{\mathrm{a}}$ & $253^{\mathrm{ab}}$ & $256^{\mathrm{abc}}$ & $251^{\mathrm{ab}}$ & $251^{\mathrm{ab}}$ & $276^{\mathrm{cd}}$ & $269^{\text {bcd }}$ & $287^{\mathrm{d}}$ & $380^{\mathrm{f}}$ & $283^{\mathrm{d}}$ & $349^{\mathrm{e}}$ \\
\hline Starch & g & $<0.001$ & $12.9^{\mathrm{a}}$ & $13.9^{\mathrm{abc}}$ & $14.0^{\text {abcd }}$ & $13.2^{\mathrm{ab}}$ & $13.2^{\mathrm{a}}$ & & & $15.2^{\mathrm{de}}$ & $21.1^{\mathrm{g}}$ & $15.3^{\mathrm{e}}$ & $18.8^{f}$ \\
\hline $\begin{array}{c}\text { Carbohydrates } \\
\text { (calculated) }\end{array}$ & g & $<0.001$ & $13.7^{\mathrm{a}}$ & $16.6^{\mathrm{fe}}$ & $15.6^{\mathrm{d}}$ & $14.7^{\mathrm{c}}$ & $14.2^{\mathrm{b}}$ & $17.0^{\mathrm{f}}$ & & & & & \\
\hline $\begin{array}{c}\text { Available } \\
\text { carbohydrates }\end{array}$ & $\%$ & $<0.001$ & $13.4^{\mathrm{a}}$ & $16.2^{\mathrm{fe}}$ & $15.2^{\mathrm{d}}$ & $14.3^{\mathrm{c}}$ & $13.7^{\mathrm{ab}}$ & $16.6^{\mathrm{fe}}$ & $14.0^{\mathrm{bc}}$ & $17.1^{\mathrm{f}}$ & $20.8^{\mathrm{h}}$ & $19.6^{\mathrm{g}}$ & \\
\hline Moisture & g & - & 80.7 & 79.1 & 79.6 & 79.6 & 79.9 & 77.8 & 80.2 & 77.6 & 73.5 & 77.4 & 72.7 \\
\hline Protein & g & $<0.001$ & $1.12^{\mathrm{c}}$ & $0.883^{\mathrm{a}}$ & $1.00^{\mathrm{b}}$ & $1.51^{\mathrm{f}}$ & $1.56^{\mathrm{g}}$ & $1.49^{\mathrm{f}}$ & $1.39^{\mathrm{e}}$ & $1.69^{\mathrm{h}}$ & $1.31^{\mathrm{d}}$ & $1.32^{\mathrm{d}}$ & $1.75^{\mathrm{i}}$ \\
\hline Fat & g & $<0.001$ & $0.00929^{b}$ & $0.0322^{\mathrm{h}}$ & $0.0211^{\mathrm{e}}$ & $0.0313^{g}$ & $0.0209^{\mathrm{d}}$ & $0.0228^{f}$ & $0.0205^{c}$ & $<0.0001^{\mathrm{a}}$ & $<0.0001^{\mathrm{a}}$ & $0.0353^{\mathrm{i}}$ & $<0.0001$ \\
\hline Calcium & $\mathrm{mg}$ & $<0.001$ & $3.09^{\mathrm{a}}$ & $3.76^{\text {cd }}$ & $3.88^{\mathrm{d}}$ & $3.32^{\mathrm{b}}$ & $3.69^{c}$ & $5.43^{\mathrm{g}}$ & $4.25^{\mathrm{e}}$ & $3.28^{\mathrm{b}}$ & $4.77^{\mathrm{f}}$ & $5.57^{\mathrm{g}}$ & $3.28^{\mathrm{b}}$ \\
\hline Phosphorus & $\mathrm{mg}$ & $<0.001$ & $52.5^{\mathrm{fg}}$ & $44.1^{\mathrm{d}}$ & $50.2^{\mathrm{e}}$ & $53.7^{\mathrm{g}}$ & $51.9^{\mathrm{efg}}$ & $35.6^{\mathrm{a}}$ & $41.5^{c}$ & $50.7^{\mathrm{ef}}$ & $70.3^{\mathrm{i}}$ & $37.6^{\mathrm{b}}$ & $65.6^{\mathrm{h}}$ \\
\hline Manganese & $\mathrm{mg}$ & $<0.001$ & $1.22^{\mathrm{ab}}$ & $1.20^{\mathrm{ab}}$ & $1.27^{\mathrm{b}}$ & $1.47^{\mathrm{c}}$ & $1.26^{\mathrm{ab}}$ & $1.44^{\mathrm{c}}$ & $1.57^{\mathrm{d}}$ & $1.51^{\mathrm{cd}}$ & $1.68^{\mathrm{e}}$ & $1.19^{\mathrm{a}}$ & $1.70^{\mathrm{e}}$ \\
\hline Magnesium & $\mathrm{mg}$ & $<0.001$ & $22.0^{\mathrm{b}}$ & $20.5^{\mathrm{ab}}$ & $20.3^{\mathrm{a}}$ & $21.8^{\mathrm{ab}}$ & $24.2^{\mathrm{c}}$ & $23.2^{\mathrm{d}}$ & $28.9^{\mathrm{e}}$ & $21.1^{\mathrm{ab}}$ & $28.7^{\mathrm{e}}$ & $27.8^{\mathrm{de}}$ & $32.8^{f}$ \\
\hline Iron & $\mathrm{mg}$ & $<0.001$ & $0.618^{\mathrm{a}}$ & $0.624^{\mathrm{a}}$ & $0.736^{\mathrm{bc}}$ & $0.685^{\mathrm{ab}}$ & $0.787^{c}$ & $0.728^{\mathrm{bc}}$ & $0.619^{\mathrm{a}}$ & $0.797^{\text {cd }}$ & $0.942^{\mathrm{e}}$ & $0.756^{\mathrm{bc}}$ & $0.869^{\mathrm{de}}$ \\
\hline Zinc & $\mathrm{mg}$ & $<0.001$ & $0.317^{\mathrm{b}}$ & $0.322^{\mathrm{bc}}$ & $0.254^{\mathrm{a}}$ & $0.376^{\mathrm{d}}$ & $0.377^{\mathrm{d}}$ & $0.343^{\mathrm{bc}}$ & $0.473^{\mathrm{f}}$ & $0.437^{\mathrm{e}}$ & $0.344^{c}$ & $0.377^{\mathrm{d}}$ & $0.465^{f}$ \\
\hline Copper & $\mathrm{mg}$ & $<0.001$ & $0.0882^{b}$ & $0.0879^{b}$ & $0.075^{\mathrm{a}}$ & $0.094^{c}$ & $0.144^{\mathrm{h}}$ & $0.119^{\mathrm{e}}$ & $0.102^{\mathrm{d}}$ & $0.139^{\mathrm{g}}$ & $0.0894^{\mathrm{b}}$ & $0.105^{\mathrm{d}}$ & $0.128^{\mathrm{f}}$ \\
\hline Potassium & $\mathrm{mg}$ & $<0.001$ & $420^{\text {cd }}$ & $401^{\mathrm{abc}}$ & $416^{\text {bcd }}$ & $440^{\mathrm{d}}$ & $475^{e}$ & $427^{\mathrm{cd}}$ & $434^{\text {cd }}$ & $383^{\mathrm{ab}}$ & $537^{\mathrm{f}}$ & $370^{\mathrm{a}}$ & $527^{\mathrm{f}}$ \\
\hline Sodium & $\mathrm{mg}$ & $<0.001$ & $7.39^{\mathrm{a}}$ & $7.59^{\mathrm{a}}$ & $7.45^{\mathrm{a}}$ & $7.73^{\mathrm{a}}$ & $7.38^{\mathrm{a}}$ & $7.77^{\mathrm{a}}$ & $7.65^{\mathrm{a}}$ & $7.45^{\mathrm{a}}$ & $9.69^{c}$ & $8.35^{\mathrm{b}}$ & $9.69^{c}$ \\
\hline DM & g & - & 19.3 & 20.9 & 20.4 & 20.4 & 20.1 & 22.2 & 19.8 & 22.4 & 26.5 & 22.6 & 27.3 \\
\hline
\end{tabular}

(Note: Means with different superscripts in a row differ significantly). 
Table 6. Nutrient content per $100 \mathrm{~g}$ of raw potato, flesh and skin.

\begin{tabular}{|c|c|c|c|c|c|c|c|c|c|c|c|c|c|}
\hline $\begin{array}{l}\text { Nutrient flesh } \\
\text { and skin }\end{array}$ & Units & $\mathrm{p}$-value & VDP & UTD & Sifra & Valor & BP1 & Mondial & Avalanche & $\begin{array}{l}\text { Buffelspoort } \\
\text { (BP13) }\end{array}$ & Darius & Fabula & Fianna \\
\hline $\begin{array}{c}\text { Energy } \\
\text { (calculated) }\end{array}$ & $\mathrm{kJ}$ & $<0.001$ & $277^{c}$ & $309^{\mathrm{de}}$ & $271^{\text {bc }}$ & $257^{\mathrm{b}}$ & $349^{f}$ & $274^{c}$ & $214^{\mathrm{a}}$ & $306^{\mathrm{de}}$ & $319^{\mathrm{e}}$ & $298^{d}$ & $305^{\mathrm{de}}$ \\
\hline Starch & g & $<0.001$ & $13.8^{\mathrm{c}}$ & $16.0^{\mathrm{f}}$ & $14.3^{\mathrm{d}}$ & $12.6^{\mathrm{b}}$ & $18.1^{\mathrm{g}}$ & $14.1^{\mathrm{cd}}$ & $10.8^{\mathrm{a}}$ & $15.2^{\mathrm{e}}$ & $17.9^{\mathrm{g}}$ & $14.9^{\mathrm{e}}$ & $15.7^{\mathrm{f}}$ \\
\hline $\begin{array}{l}\text { Carbohydrates } \\
\text { (calculated) }\end{array}$ & g & $<0.001$ & $17.5^{\mathrm{c}}$ & $20.1^{\mathrm{h}}$ & $17.5^{\mathrm{c}}$ & $16.3^{\mathrm{b}}$ & $21.6^{\mathrm{i}}$ & $17.6^{\mathrm{d}}$ & $14.4^{\mathrm{a}}$ & $18.7^{\mathrm{f}}$ & $22.0^{\mathrm{j}}$ & $18.5^{\mathrm{e}}$ & $19.4^{\mathrm{g}}$ \\
\hline $\begin{array}{c}\text { Available } \\
\text { carbohydrates }\end{array}$ & $\%$ & $<0.001$ & $15.1^{\mathrm{C}}$ & $16.8^{\mathrm{de}}$ & $14.8^{\mathrm{c}}$ & $13.8^{\mathrm{b}}$ & $18.5^{f}$ & $14.6^{\mathrm{bc}}$ & $11.6^{\mathrm{a}}$ & $16.4^{\mathrm{d}}$ & $17.4^{\mathrm{e}}$ & $16.1^{\mathrm{d}}$ & $16.9^{\mathrm{de}}$ \\
\hline Moisture & g & - & 80.6 & 77.6 & 80.7 & 81.6 & 75.5 & 80.1 & 83.8 & 78.8 & 75.5 & 79.1 & 78.8 \\
\hline Protein & g & $<0.001$ & $1.15^{\mathrm{c}}$ & $1.16^{\mathrm{c}}$ & $1.00^{\mathrm{a}}$ & $1.35^{\mathrm{e}}$ & $1.96^{\mathrm{h}}$ & $1.45^{\mathrm{f}}$ & $1.03^{\mathrm{b}}$ & $1.65^{\mathrm{g}}$ & $1.32^{\mathrm{d}}$ & $1.47^{\mathrm{f}}$ & $1.05^{\mathrm{b}}$ \\
\hline Fat & g & $<0.001$ & $<0.0001^{\mathrm{a}}$ & $0.10^{\mathrm{f}}$ & $0.059^{\mathrm{e}}$ & $<0.0001^{\mathrm{a}}$ & $<0.0001^{\mathrm{a}}$ & $0.030^{\mathrm{a}}$ & $0.01^{\mathrm{b}}$ & $<0.0001^{\mathrm{a}}$ & $0.050^{\mathrm{d}}$ & $<0.0001^{\mathrm{a}}$ & $<0.0001^{\mathrm{a}}$ \\
\hline Calcium & $\mathrm{mg}$ & $<0.001$ & $3.48^{\mathrm{a}}$ & $5.49^{f}$ & $4.35^{\mathrm{c}}$ & $4.77^{\mathrm{e}}$ & $4.51^{\mathrm{d}}$ & $6.86^{\mathrm{i}}$ & $3.57^{\mathrm{a}}$ & $3.91^{\mathrm{b}}$ & $5.84^{\mathrm{g}}$ & $6.01^{\mathrm{h}}$ & $4.23^{\mathrm{c}}$ \\
\hline Phosphorus & $\mathrm{mg}$ & $<0.001$ & $50.2^{\mathrm{ef}}$ & $57.3^{\mathrm{g}}$ & $42.7^{c}$ & $45.4^{\mathrm{d}}$ & $58.9^{\mathrm{h}}$ & $30.8^{\mathrm{a}}$ & $38.9^{\mathrm{b}}$ & $50.3^{\mathrm{ef}}$ & $72.9^{\mathrm{i}}$ & $49.3^{\mathrm{e}}$ & $50.7^{\mathrm{f}}$ \\
\hline Manganese & $\mathrm{mg}$ & $<0.001$ & $0.976^{\mathrm{cd}}$ & $1.29^{\mathrm{f}}$ & $0.756^{\mathrm{a}}$ & $0.976^{\mathrm{cd}}$ & $1.48^{\mathrm{g}}$ & $1.31^{\mathrm{f}}$ & $0.866^{\mathrm{b}}$ & $1.25^{\mathrm{f}}$ & $1.03^{\mathrm{de}}$ & $1.08^{\mathrm{e}}$ & $0.917^{\mathrm{bc}}$ \\
\hline Magnesium & $\mathrm{mg}$ & $<0.001$ & $23.7^{\mathrm{c}}$ & $23.4^{\mathrm{bc}}$ & $20.1^{\mathrm{a}}$ & $21.8^{\mathrm{ab}}$ & $28.5^{\mathrm{d}}$ & $27.5^{\mathrm{d}}$ & $21.7^{\mathrm{ab}}$ & $24.2^{\mathrm{C}}$ & $31.5^{\mathrm{e}}$ & $28.2^{\mathrm{d}}$ & $23.4^{\mathrm{bc}}$ \\
\hline Iron & $\mathrm{mg}$ & $<0.001$ & $0.865^{\mathrm{b}}$ & $1.35^{\mathrm{e}}$ & $1.25^{\mathrm{d}}$ & $1.12^{\mathrm{c}}$ & $1.44^{\mathrm{f}}$ & $0.788^{\mathrm{a}}$ & $0.885^{\mathrm{b}}$ & $1.24^{\mathrm{d}}$ & $1.38^{\mathrm{ef}}$ & $1.41^{\mathrm{ef}}$ & $1.10^{\mathrm{c}}$ \\
\hline Zinc & $\mathrm{mg}$ & $<0.001$ & $0.282^{\mathrm{b}}$ & $0.419^{\mathrm{g}}$ & $0.249^{\mathrm{a}}$ & $0.344^{\text {cd }}$ & $0.491^{\mathrm{h}}$ & $0.327^{c}$ & $0.370^{\text {de }}$ & $0.415^{\mathrm{fg}}$ & $0.367^{\mathrm{de}}$ & $0.389^{\text {ef }}$ & $0.331^{\mathrm{c}}$ \\
\hline Copper & $\mathrm{mg}$ & $<0.001$ & $0.0795^{\mathrm{b}}$ & $0.0999^{\mathrm{d}}$ & $0.0697^{\mathrm{a}}$ & $0.0765^{\mathrm{b}}$ & $0.147^{\mathrm{f}}$ & $0.102^{\mathrm{d}}$ & $0.0689^{\mathrm{a}}$ & $0.127^{\mathrm{e}}$ & $0.0899^{c}$ & $0.0986^{\mathrm{d}}$ & $0.0796^{\mathrm{b}}$ \\
\hline Potassium & $\mathrm{mg}$ & $<0.001$ & $406^{\mathrm{b}}$ & $545^{\mathrm{f}}$ & $349^{\mathrm{a}}$ & $366^{\mathrm{a}}$ & $497^{\mathrm{e}}$ & $410^{\mathrm{b}}$ & $412^{\mathrm{b}}$ & $433^{c}$ & $618^{\mathrm{g}}$ & $462^{\mathrm{d}}$ & $477^{\mathrm{d}}$ \\
\hline Sodium & $\mathrm{mg}$ & $<0.001$ & $6.77^{\mathrm{a}}$ & $9.79^{c}$ & $7.04^{\mathrm{a}}$ & $6.77^{\mathrm{a}}$ & $9.85^{\mathrm{c}}$ & $8.11^{\mathrm{b}}$ & $6.81^{\mathrm{a}}$ & $8.22^{\mathrm{b}}$ & $10.9^{\mathrm{d}}$ & $8.30^{\mathrm{b}}$ & $7.08^{\mathrm{a}}$ \\
\hline DM & g & - & 19.4 & 22.4 & 19.3 & 18.4 & 24.5 & 19.9 & 16.2 & 21.2 & 24.5 & 20.9 & 21.3 \\
\hline
\end{tabular}

(Note: Means with different superscripts in a row differ significantly).

was calculated using the Atwater conversion factor for protein, carbohydrates and fat [34]. Carbohydrate content is higher in the skin which leads to a higher energy value of tubers with the skin as seen between cultivars in Table 5 and Table 6.

Starch content did not differ significantly between Van der Plank, UTD, Sifra, Valor and BP1. Darius had the highest starch content of $21.1 \mathrm{~g} / 100 \mathrm{~g}$. Starch is linked to cooking and processing qualities in the chipping industry [43].

Although the protein content is low in potatoes it occurs in a highly bioavailable form. A study conducted in Germany in 1997 and Pakistan in 2011 found a significant difference in the protein content of different cultivars [44] [45]. In a study conducted in Jordan, in which the Mondial cultivar was also included, it was observed to have the lowest protein content of all the cultivars in that trial. In the current study (Table 5), Mondial had an average protein content of $1.49 \mathrm{~g} / 100 \mathrm{~g}$ when compared to the other cultivars included in the study. The United States Department of Agriculture (USDA) food database reports protein values of white potato tubers to be between $1.00-1.97 \mathrm{~g} / 100 \mathrm{~g}$. The New Zealand and Australian food database reports protein levels of $2.3 \mathrm{~g} / 100 \mathrm{~g}$. These levels are slightly higher than the levels found in the current study. Protein content differs significantly between cultivars $(0.883-1.75 \mathrm{~g} / 100 \mathrm{~g})$ with Buffelspoort and Fianna containing almost double the protein found in UTD. Potatoes are one of the best plant sources of the amino acid lysine (although not determined in this study) [41]. Lysine is one of the amino acids that is a necessary component of complete proteins. Protein-energy malnutrition is a regular occurrence in sub-Saharan Africa. The consumption of animal and plant based foods can increase the consumption of complete proteins [46].

Potatoes are naturally very low in fat [47] with an average fat content of $0.0176 \mathrm{mg} / 100 \mathrm{~g}$ as seen in Table 5 . Three of the cultivars contained no detectable fat. The United States Potato Board states that potatoes are naturally fat free, contain no saturated fat and no cholesterol (United States Potato Board, 2013; McGregor, 2011). 
Potatoes can therefore be promoted as a fat free food in a country with high rates of obesity such as South Africa where $39.2 \%$ of women and $20.2 \%$ of men are classified as being either overweight or obese [48]. Although fat content in all cultivars was very low, statistically significant differences were observed between most cultivars ( $<<0.001$ ). At such a low level these differences make little difference to the human diet.

A review of American grown potatoes showed an average zinc content of $0.35 \mathrm{mg} / 100 \mathrm{~g}$ which decreased to $0.30 \mathrm{mg} / 100 \mathrm{~g}$ when the potatoes were boiled with its skin. The zinc content can decrease by up to $50 \%$ when boiled without the skin. The value for zinc is similar to the values found in the current study. Avalanche had the highest zinc content, $0.473 \mathrm{mg} / 100 \mathrm{~g}$ and Sifra the lowest, $0.254 \mathrm{mg} / 100 \mathrm{~g}$. Zinc and iron deficiencies are among the main causes of child morbidity in African countries as a deficiency of these minerals can lead to increase infections [49]. Potatoes generally have a low phytate content which results in a lower inhibitory effect on minerals such as iron and zinc and lead to better absorption of these minerals.

Compared to other vegetables, the potato is one of the best sources of dietary potassium [50]. Apart from nitrogen, potassium is the most essential mineral for plant formation and growth. Correct potassium levels improve crop yield, tuber quality, decrease bruising and decrease sugar levels which in turn increase storability. This ensures that tubers can be stored for a longer period of time after harvesting [51]. Potatoes can be a notable sources of potassium in the human diet [52] with a $100 \mathrm{~g}$ tuber contributing up to $15 \%$ of daily nutrient reference values for potassium [40]. Boiling a potato without the skin can reduce its potassium content by up to $50 \%$ [26]. The tubers in this study had an average potassium content of $439 \mathrm{mg} / 100 \mathrm{~g}$. Darius (537 mg/100g) and Fianna (527 mg/100g) contained the highest amounts potassium and Fabula (370 mg/100g), UTD (401 mg/100g) and Buffeslpoort (383 mg/100g) the lowest. These levels are consistent with those reported in New Zealand and Australia [53].

Together with high levels of potassium, potatoes are naturally low in sodium [54]. High sodium consumption is seen all over the world as the ingestion of processed foods increases [55]. Fruit and vegetables in their natural form are low in sodium and a heart healthy option that can decrease the likelihood of hypertension and heart disease [56]. The sodium content of the potatoes in this study varied between $7.38 \mathrm{mg} / 100 \mathrm{~g}$ and $9.69 \mathrm{mg} / 100 \mathrm{~g}$ with BP1 having the lowest, and Avalanche and Fianna the highest values. In many countries potassium consumption is decreasing due to a decreased consumption of fruits and vegetables and sodium intake is increasing due to over-consumption of processed food [57]. Potatoes consumed in their fresh form can be part of the solution to overturn this trend.

\subsection{Nutrient Contribution to Culinary Application}

The phosphorus content of potatoes has been shown to be directly influenced by the phosphorus concentration in the fertilizer used during production. Correct phosphorus fertilisation of plants increases the yield, but can have a negative effect on the availability of other micronutrients in the soil [58]. Phosphorus levels differed significantly between cultivars with a wide range and an average of $50.3 \mathrm{mg} / 100 \mathrm{~g}$, a lowest value of $35.6 \mathrm{mg} / 100 \mathrm{~g}$ found in Mondial and a highest value of $70.3 \mathrm{mg} / 100 \mathrm{~g}$ in Darius (Table 5).

According to the literature, dry matter values of potatoes most commonly range between 16.5\% - 24\% [59]. There is a significant difference in the distribution of dry matter throughout the flesh and skin of the tuber. Peeling, slicing and handling can have an effect on the dry matter content of a tuber. With this all taken into account, dry matter is still the best way to evaluate the total quantity of solids in a tuber [60]. In Table 5 dry matter values range between $19.3 \mathrm{mg} / 100 \mathrm{~g}$ for Van der Plank and $27.3 \mathrm{mg} / 100 \mathrm{~g}$ for Fianna. The higher the dry matter content, the lower the water content, which will mean that such a potato has a higher specific gravity. Potatoes with a higher dry matter and low moisture content are mealy, ideal for baking, and potatoes with low dry matter and high moisture content are waxy and ideal for boiling [61].

\subsection{Nutrient Contribution to Plant Growth}

Certain minerals found in in tubers, be it in trace or significant amounts, contribute to the plants growth and formation.

Calcium differed significantly between the cultivars, $\mathrm{p}<0.001$. Calcium levels were found between 3.09 $\mathrm{mg} / 100 \mathrm{~g}$ in Van der Plank and $5.56 \mathrm{mg} / 100 \mathrm{~g}$ in Fabula. The calcium content of potatoes is low and does not contribute meaningfully to the human diet [62]. The calcium content of tubers does however, play an important role in cell wall structure, which in turn play an important role in texture and eating quality. It increases cell wall 
stability because it strengthens the links between cells [63]. Fruit and vegetable firmness is essentially determined by the strength of the cell walls. Stronger cell structures also decrease the chance that a potato will form brown or bruised spots [51]. This is of significance in relation to machine harvested tubers that are exposed to rough handling. Higher cell wall stability can also increase the storage life of the product [64].

Like phosphorus, manganese contributes to the total yield of the potato crop resulting in a larger overall crop yield which can contribute to food security (Scott, 2010). Manganese values ranged between $1.19 \mathrm{mg} / 100 \mathrm{~g}$ for Fabula and $1.68 \mathrm{mg} / 100 \mathrm{~g}$ for Darius and $1.70 \mathrm{mg} / 100 \mathrm{~g}$ for Fianna. Manganese is one of the minerals that decreases significantly when a potato is boiled without the peel [65]. In this study a strong correlation was seen between manganese and protein values $(r=0.7209)$.

The main uptake of magnesium by tubers occurs during the tuber initiation phase which is at 31 - 40 days [66]. A 290 g serving of cooked potato can provide up to $24 \%$ of the required daily allowance of magnesium. The South African values for magnesium in potatoes are higher than those seen in New Zealand and Australia where potatoes have an average of $20 \mathrm{mg} / 100 \mathrm{~g}$ [53]. Fianna had the highest magnesium content of $32.8 \mathrm{mg} / 100 \mathrm{~g}$ and Sifra the lowest, at $20.3 \mathrm{mg} / 100 \mathrm{~g}$. In this study iron values were at a low of $0.618 \mathrm{mg} / 100 \mathrm{~g}$ in Van der Plank and a high of $0.942 \mathrm{mg} / 100 \mathrm{~g}$ in Darius, which according to the USDA is correlated with colour differences between cultivars [67].

Zinc together with copper is essential during the plant formation stage [68]. Copper levels were found to be between $0.0751 \mathrm{mg} / 100 \mathrm{~g}$ of Sifra and $0.144 \mathrm{mg} / 100 \mathrm{~g}$ of BP1. These are higher concentrations than those found in potatoes from Australia and New Zealand. In their combined food database they reported that potatoes contain $0.038 \mathrm{mg} / 100 \mathrm{~g}$ copper [53]. The results of the present study is also higher than levels reported in Korean potatoes which had an average copper content of $0.067 \mathrm{mg} / 100 \mathrm{~g}$ [69]. These variations could be due to the effect of irrigation water, as well as postharvest activities [70].

\section{Conclusion and Recommendations}

Potatoes contain significant amounts of potassium and are naturally low in sodium. A medium size potato (100 g) contributes up to $60 \%$ of the daily nutrient reference value for manganese. On average tubers contain 0.0177 $\mathrm{g} / 100 \mathrm{~g}$ making them a naturally low fat product.

Sub-Saharan Africa is struggling to overcome food insecurity and the micronutrient deficiency epidemic. This can be blamed on the lack of dietary diversity and the consumption of energy dense and nutrient poor foods. Therefore an easy-to-grow nutrient dense carbohydrate crop can be promoted to overcome the problem of a monotonous nutrient poor diet. Potatoes can be promoted as a nutrient dense crop for subsistence farmers to increase dietary diversity for rural households.

\section{Acknowledgements}

The author would like to acknowledgement the support of the University of Pretoria Institutional Research Theme on Food, Nutrition and Well-being, as well as the Agricultural Research Council, Irene, Potatoes South Africa, Coenrad Fick for planting the tubers used in the study and Marie Smith for statistical analysis.

\section{References}

[1] FAO. FAO—Special Event: Food Security and Genetic Diversity. http://www.fao.org/webcast/home/en/item/3153/icode/

[2] Jones, A.D., et al. (2013) What Are We Assessing When We Measure Food Security? A Compendium and Review of Current Metrics. Advances in Nutrition, 4, 481-505.

[3] Food and Agricultural Organisation. FAO Stats. http://faostat3.fao.org/home/E

[4] Schönfeldt, H.C., Kirsten, J.F. and McClachlan, M. (2014) Country Policy Analysis: Nutrition Impact of Agriculture and Food Systems South Africa. United Nations, Pretoria.

[5] FAO, IFAD and WFP (2014) The State of Food Security in the World. FAO, Rome.

[6] United Nations (2015) United Nations-Millennium Development Goals and Beyond. http://www.un.org/millenniumgoals/poverty.shtml

[7] Meade, B. and Rosen, S. (2013) International Food Security Assessment, 2013-2023, GFA-24. US Department of Agriculture, Economic Research Service, US. 
[8] Bommarco, R., Kleijn, D. and Potts, S.G. (2013) Ecological Intensification: Harnessing Ecosystem Services for Food Security. Trends in Ecology \& Evolution, 28, 230-238.

[9] Tanuminhardjo, S.A., et al. (2007) Poverty, Obesity, and Malnutrition: An International Perspective Recognizing the Paradox. Journal of the American Dietetic Association, 107, 1966-1972.

[10] Lear, S.A., et al. (2014) The Association between Ownership of Common Household Devices and Obesity and Diabetes in High, Middle and Low Income Countries. Canadian Medical Association Journal, 186, 258-266.

[11] Shisana, O., et al. (2014) The South African National Health and Nutrition Examination Survey SANHANES-1. HSRC Press, Cape Town.

[12] Khoury, C.K., et al. (2014) Increasing Homogeneity in Global Food Supplies and the Implications for Food Security. Proceedings of the National Academy of Sciences, 111, 4001-4006.

[13] Popkin, B.M., Adair, L.S. and Ng, S.W. (2012) Global Nutrition Transition and the Pandemic of Obesity in Developing Countries. Nutrition Reviews, 70, 3-21.

[14] Smith, L.C. and Haddad, L. (2015) Reducing Child Undernutrition: Past Drivers and Priorities for the Post-MDG Era. World Development, 68, 180-204. http://dx.doi.org/10.1016/j.worlddev.2014.11.014

[15] Papathakis, P.C. and Pearson, K.E. (2012) Food Fortification Improves the Intake of All Fortified Nutrients, But Fails to Meet the Estimated Dietary Requirements for Vitamins A and B6, Riboflavin and Zinc, in Lactating South African Women. Public Health Nutrition, 15, 1810-1817.

[16] Grubben, G., et al. (2014) Vegetables to Combat the Hidden Hunger in Africa. Chronica Horticulturae, 54, $24-32$.

[17] Muthayya, S., et al. (2013) The Global Hidden Hunger Indices and Maps: An Advocacy Tool for Action. PloS One, 8, 67860.

[18] McCormick, C.L., et al. (2014) Increasing Obesity in Treated Female HIV Patients from Sub-Saharan Africa: Potential Causes and Possible Targets for Intervention. Frontiers in Immunology, 5, 5-12.

[19] Jaime, P.C., et al. (2013) Brazilian Obesity Prevention and Control Initiatives. Obesity Reviews, 14, 88-95.

[20] Toledo, A. and Burlingame, B. (2006) Biodiversity and Nutrition: A Common Path toward Global Food Security and Sustainable Development. Journal of Food Composition and Analysis, 19, 477-483.

[21] SANBI. 2015. [Online] http://www.sanbi.org/information

[22] Potatoes South Africa. 2015. [Online] http://www.potatoes.co.za/SiteResources/documents/Potato\%20production\%20in\%2016\%20regions.pdf

[23] International Potato Center (2014) Research—Potato Highlands. [Online] http://cipotato.org/potato/

[24] Drewnowski, A. and Specter, S.E. (2004) Poverty and Obesity: The Role of Energy Density and Energy Costs. The American Journal of Clinical Nutrition, 79, 6-16.

[25] Drewnowski, A. and Rehm, C.D. (2013) Vegetable Cost Metrics Show That Potatoes and Beans Provide Most Nutrients per Penny. PLoS ONE, 8, e63277. http://dx.doi.org/10.1371/journal.pone.0063277

[26] Potatoes South Africa (2014) Industry Report. [Online] http://www.potatoes.co.za/industry-information.aspx

[27] Food Composition Database (1999) South African Food Data System. [Online] http://safoods.mrc.ac.za/foodcomp.htm

[28] Denner, F. and Venter, S. (2011) Handleiding vir aartappelproduksie in Suid-Afrika. 2nd Edition, Potateos South Africa, Pretoria.

[29] Nortje, P., Kleingeld, C. and Visser, A. (2000) Potato Breeding, Evaluation and Commercialisation in South Africa and Opportunities for Australia. Australian Potato Research, Adelaide.

[30] Potatoes South Africa (2013) Industry Report. [Online] http://www.potatoes.co.za/industry-information.aspx

[31] Lin, T.M., Durance, T. and Scaman, C.H. (1998) Characterization of Vacuum Microwave, Air and Freeze Dried Carrot Slices. Food Research International, 31, 111-117. http://dx.doi.org/10.1016/S0963-9969(98)00070-2

[32] Giron, H.C. (1973) Perkin Elmer Atomic Spectrophotometer. Atomic Absorption Newsletter, 12, 28.

[33] Gilani, G.S. and Nasim, A. (2007) Impact of Foods Nutritionally Enhanced through Biotechnology in Alleviating Malnutrition in Developing Countries. Journal of AOAC International, 90, 1440-1444.

[34] Greenfield, H. and Southgate, D.A. (2003) Food Composition Data. FAO Publishing Management Service, Rome.

[35] Payne, R.W., Murray, D.A., Harding, S.A., Baird, D.B. and Soutar, D.M. (2012) GenStat ${ }^{\circledR}$ for Windows ${ }^{\mathrm{TM}}$ Introduc- $^{-}$ tion. 15th Edition, VSN International, Hemel Hempstead.

[36] Steyn, N., Nel, J. and Labadarios, D. (2009) Will Fortification of Staple Foods Make a Difference to the Dietary Intake of South African Children? South African Journal of Clinical Nutrition, 21, 22-26. 
[37] Parsa, S., Ccanto, R. and Rosenheim, J. (2011) Resource Concentration Dilutes a Key Pest in Indigenous Potato Agriculture. Ecological Applications, 21, 539-546. http://dx.doi.org/10.1890/10-0393.1

[38] Slavin, J.L. (2013) Carbohydrates, Dietary Fiber, and Resistant Starch in White Vegetables: Links to Health Outcomes. Advances in Nutrition, 4, 351-355. http://dx.doi.org/10.3945/an.112.003491

[39] King, J.C. and Slavin, J.L. (2013) White Potatoes, Human Health, and Dietary Guidance. Advances in Nutrition, 4, 393-401. http://dx.doi.org/10.3945/an.112.003525

[40] Department of Health (2014) Foodstuffs, Cosmetics and Disinfectant Act, 1972 (ACT No.54 of 1972) Regulations Relating to the Labelling and Advertising of Foods: Amendment (R429 of May 2014). Government Gazette, Pretoria.

[41] Peksa, A., Kita, A., Kułakowska, K., Aniołowska, M., Hamouz, K. and Nemś, A. (2013) The Quality of Protein of Coloured Fleshed Potatoes. Food Chemistry, 141, 2960-2966. http://dx.doi.org/10.1016/j.foodchem.2013.05.125

[42] Murniece, I., Karklina, D., Galoburda, R., Santare, D., Skrabule, I. and Costa, H.S. (2011) Nutritional Composition of Freshly Harvested and Stored Latvian Potato (Solanum tuberosum L.) Varieties Depending on Traditional Cooking Methods. Journal of Food Composition and Analysis, 24, 699-710. http://dx.doi.org/10.1016/j.jfca.2010.09.005

[43] Jansky, S.H. and Fajardo, D.A. (2014) Tuber Starch Amylose Content Is Associated with Cold-Induced Sweetening in Potato. Food Science \& Nutrition, 2, 628-633. http://dx.doi.org/10.1002/fsn3.137

[44] Abbas, G., Frooq, K., Hafiz, I.A., Hussain, A., Abbasi, N.A. and Shabbir, G. (2011) Assessment of Processing and Nutritional Quality of Potato Genotypes in Pakistan. Pakistan Journal of Agricultural Science, 48, 169-175.

[45] Jansen, G., Flamme, W., Schüler, K. and Vandrey, M. (2001) Tuber and Starch Quality of Wild and Cultivated Potato Species and Cultivars. Potato Research, 44, 137-146. http://dx.doi.org/10.1007/BF02410100

[46] Schönfeldt, H.C. and Gibson Hall, N. (2012) Dietary Protein Quality and Malnutrition in Africa. British Journal of Nutrition, 108, 69-76. http://dx.doi.org/10.1017/S0007114512002553

[47] Luis, G., Rubio, C., González-Weller, D., Gutiérrez, A.J., Revert, C. and Hardisson, A. (2011) Comparative Study of the Mineral Composition of Several Varieties of Potatoes (Solanum tuberosum L.) from Different Countries Cultivated in Canary Islands (Spain). International Journal of Food Science \& Technology, 46, 774-780. http://dx.doi.org/10.1111/j.1365-2621.2011.02556.x

[48] Steyn, N.P., Labadarios, D. and Nel, J.H. (2011) Factors Which Influence the Consumption of Street Foods and Fast Foods in South Africa-A National Survey. Nutrition Journal, 10, 104-114. http://dx.doi.org/10.1186/1475-2891-10-104

[49] Sazawal, S., Dhingra, P., Dhingra, U., Gupta, S., Iyengar, V., Menon, V.P., Sarkar, A. and Black, R.E. (2014) Compliance with Home-Based Fortification Strategies for Delivery of Iron and Zinc: Its Effect on Haematological and Growth Markers among 6-24 Months Old Children in North India. Journal of Health, Population, and Nutrition, 32, 217-226.

[50] Weichselbaum, E. (2010) REVIEW: An Overview of the Role of Potatoes in the UK Diet. Nutrition Bulletin, 35, 195206. http://dx.doi.org/10.1111/j.1467-3010.2010.01845.X

[51] Brown, C.R., Haynes, K.G., Moore, M., Pavek, M.J., Hane, D.C., Love, S.L. and Novy, R.G. (2013) Stability and Broad-Sense Heritability of Mineral Content in Potato: Potassium and Phosphorus. American Journal of Potato Research, 90, 516-523. http://dx.doi.org/10.1007/s12230-013-9323-2

[52] Storey, M.L. and Anderson, P. (2013) White Potato Consumption Is Positively Associated with Potassium Intake. The FASEB Journal, 27, 1062-1100.

[53] Food Standards Australia New Zealand (2014) NUTTAB. [Online] http://www.foodstandards.gov.au/science/monitoringnutrients/nutrientables/nuttab/Pages/default.aspx

[54] McGill, C.R., Kurilich, A.C. and Davingnon, J. (2013) The Role of Potatoes and Potato Components in Cardiometabolic Health: A Review. Annals of Medicine, 45, 467-473. http://dx.doi.org/10.3109/07853890.2013.813633

[55] Garcia-Garcia, E. and Totosaus, A. (2008) Low-Fat Sodium-Reduced Sausages: Effect of the Interaction between Locust Bean Gum, Potato Starch and $\kappa$-Carrageenan by a Mixture Design Approach. Meat Science, 78, 406-413. http://dx.doi.org/10.1016/j.meatsci.2007.07.003

[56] Flock, M.R. and Kris-Etherton, P.M. (2011) Dietary Guidelines for Americans 2010: Implications for Cardiovascular Disease. Current Atherosclerosis Reports, 13, 499-507. http://dx.doi.org/10.1007/s11883-011-0205-0

[57] Steffen, L.M. (2014) Lower Levels of Sodium Intake and Reduced Cardiovascular Risk The Challenge to Achieve Lower Sodium Recommendations. Circulation, 129, 956-957. http://dx.doi.org/10.1161/CIRCULATIONAHA.114.007964

[58] Monteiro, A., Henriques, I. and Moreira, I. (2011) Critical Period for Weed Control in Potatoes in the Huambo Province (Angola). Planta Daninha, 29, 351-362. http://dx.doi.org/10.1590/S0100-83582011000200013

[59] Fernando, N. and Slater, T. (2010) State Government Victoria, Department of Environment and Primary Industry. [On- 
line] http://www.dpi.vic.gov.au/agriculture/horticulture/vegetables/potatoes/potatoes-factors-affecting-dry-matter

[60] Thybo, A.K., Molgaard, J.P. and Kidmose, U. (2002) Effect of Different Organic Growing Conditions on Quality of Cooked Potatoes. Journal of the Science of Food and Agriculture, 82, 12-18. http://dx.doi.org/10.1002/jsfa.1009

[61] South African Department of Environment and Primary Industries (2000) Agriculture—Potatoes. [Online] http://www.dpi.vic.gov.au/agriculture/horticulture/vegetables/potatoes/potatoes-measurement-specific-gravity

[62] Camire, M.E., Kubow, S. and Donnelly, D.J. (2009) Potatoes and Human Health. Critical Reviews in Food Science and Nutrition, 49, 823-840. http://dx.doi.org/10.1080/10408390903041996

[63] Palta, J.P. (1996) Role of Calcium in Plant Responses to Stresses: Linking Basic Research to the Solution of Practical Problems. HortScience, 31, 51-57.

[64] Van der Waals, J.E., Korsten, L. and Slippers, B. (2004) Genetic Diversity among Alternaria solani Isolates from Potatoes in South Africa. Plant Disease, 88, 959-964. http://dx.doi.org/10.1094/PDIS.2004.88.9.959

[65] Dugo, G., La Pera, L., Lo Turcoa, V., Palmieri, R.M. and Saitta, M. (2005) Effect of Boiling and Peeling on Manganese Content of Some Vegetables Determined by Derivative Anodic Stripping Chronopotentiometry (DASCP). Food Chemistry, 93, 703-711. http://dx.doi.org/10.1016/j.foodchem.2004.12.037

[66] Zhao, Y.-X., Meng, M.-L., Hao, W.-S. and Sun, S.-Y. (2010) A Study on the Magnesium Absorption of Potatoes. Acta Agriculturae Boreali-Sinica, 25, 190-193.

[67] United States Department of Agriculture. 2012. [Online] http://www.ers.usda.gov/topics/crops/vegetables-pulses/potatoes.aspx\#.U5GQgyh7yao

[68] Dugo, G., La Pera, L., Lo Turcoa, V., Giuffrida, D. and Restuccia, S. (2004) Determination of Copper, Zinc, Selenium, Lead and Cadmium in Potatoes (Solanum tuberosum L.) Using Potentiometric Stripping Methods. Food Additives and Contaminants, 21, 649-657. http://dx.doi.org/10.1080/02652030410001698698

[69] Choi, M.K., Kang, M.H. and Kim, M.H. (2009) The Analysis of Copper, Selenium, and Molybdenum Contents in Frequently Consumed Foods and an Estimation of Their Daily Intake in Korean Adults. Biological Trace Element Research, 128, 104-117. http://dx.doi.org/10.1007/s12011-008-8260-2

[70] Moretti, C.L., Mattos, L.M., Calbo, A.G. and Sargent, S.A. (2010) Climate Changes and Potential Impacts on Postharvest Quality of Fruit and Vegetable Crops: A Review. Food Research International, 43, 1824-1832. http://dx.doi.org/10.1016/j.foodres.2009.10.013 